\title{
Satellite-tracking reveals multiple foraging strategies and threats for olive ridley turtles in Brazil
}

\author{
Augusto C. C. D. da Silva ${ }^{1, *}$, Erik A. P. dos Santos ${ }^{1}$, Fábio L. das C. Oliveira ${ }^{2}$, \\ Marilda I. Weber ${ }^{2}$, Jamyle A. F. Batista ${ }^{2}$, Thiago Z. Serafini ${ }^{3}$, Jaqueline C. de Castilhos $^{2}$ \\ ${ }^{1}$ Centro Nacional de Conservação, Pesquisa e Manejo das Tartarugas Marinhas, ReBio Santa Isabel, 49190-000, Pirambu, SE, \\ Brazil \\ ${ }^{2}$ Fundação Centro Brasileiro de Proteção e Pesquisa das Tartarugas Marinhas, 49035-485, Aracaju, SE, Brazil \\ ${ }^{3}$ Programa de Pós-Graduação em Meio Ambiente e Desenvolvimento - MADE, Universidade Federal do Paraná - UFPR, \\ 80035-050, Curitiba, PR, Brazil
}

\begin{abstract}
The state of Sergipe in northeastern Brazil is the largest nesting area for olive ridley turtles along this nation's coast, and constitutes a major rookery in the western Atlantic as well. Conservation efforts with a focus on nesting activities have been implemented there since 1982, but little is known about other aspects of the life cycle, specifically post-nesting movements of females and the locations of foraging grounds. To address this issue, satellite transmitters were deployed on 10 females that nested between February and April 2006. The turtles were monitored for an average of $113 \mathrm{~d}$ (range: 14 to $297 \mathrm{~d}$ ), and an average movement of $1669 \mathrm{~km}$ (range: 407 to $4265 \mathrm{~km}$ ) was recorded. Of the 10 turtles monitored, 6 moved along the Brazilian continental shelf to neritic foraging areas. Five of these turtles utilized foraging areas along the northern and northeastern coasts of Brazil, while one foraged along the southeastern coastline. Two females were tracked to equatorial oceanic waters, with one first moving to an inshore foraging site where she remained for $34 \mathrm{~d}$ before migrating to oceanic waters off the Brazilian coast. Signal transmission of 3 of the 10 turtles tracked ceased during their post-nesting migrations, preventing identification of their feeding areas. Olive ridley turtles nesting on the coast of Sergipe displayed a range of post-nesting movements including to coastal sites along the continental shelf as well as offshore oceanic areas. Inter-nesting habitats, migration routes and foraging grounds showed great overlap with a variety of coastal fisheries, as well as with longline fishing in oceanic waters, a key consideration for developing conservation strategies for this species in the western Atlantic.
\end{abstract}

KEY WORDS: Satellite tracking $\cdot$ Inter-nesting $\cdot$ Migration $\cdot$ Foraging grounds $\cdot$ Lepidochelys olivacea $\cdot$ Conservation $\cdot$ Brazil

\section{INTRODUCTION}

The olive ridley Lepidochelys olivacea is considered to be the most abundant sea turtle species and is distributed throughout tropical and subtropical ocean basins worldwide (Pritchard 1997). Despite this relative abundance, olive ridleys are classified as globally vulnerable in the IUCN Red List (AbreuGrobois \& Plotkin 2008).All sea turtles hatch from eggs on nesting beaches and then enter the ocean.
The life history of olive ridleys is not well known, and their life cycle may include neritic and/or oceanic stages for juveniles and adults, depending on differences in resource availability between regions (Bolten 2003). North Pacific olive ridley juveniles, for example, are associated with warmer oceanic waters in the center of the subtropical gyre (Polovina et al. 2004). In contrast, in the eastern tropical Pacific, where large juveniles and adults are relatively abundant (Eguchi et al. 2007), post-nesting females pre- 
sent nomadic oceanic migratory behaviors characterized by non-directional movements and highly flexible responses to changing environmental conditions (Swimmer et al. 2009, Plotkin 2010). Moreover, in Australia, olive ridley turtles do not undertake extensive migrations, remaining instead in coastal neritic waters close to their nesting grounds (McMahon et al. 2007, Whiting et al. 2007).

In the Atlantic Ocean, nesting grounds of the olive ridley turtles are found in the western hemisphere mainly in northeastern Brazil, Suriname and French Guiana (Fretey 1999, da Silva et al. 2007), whereas along the African coast they are located between Guinea Bissau and Angola (Fretey 2001). Behavioral differences and a lack of tag recoveries among the different nesting areas support the distinctiveness of the Brazilian rookery from others in the Atlantic (Godfrey \& Chevalier 2004), although the Brazilian population shares mitochondrial DNA markers with those in Surinam and Guinea Bissau, and Brazil and Surinam are not currently distinguishable genetically (Bowen et al. 1998, A. Torres Hahn pers. comm.).

In Brazil, conservation efforts have been undertaken since 1982, starting with protection and monitoring of nesting beaches, then extending to feeding grounds (Marcovaldi \& dei Marcovaldi 1999) and monitoring and mitigation of fishery interactions (Marcovaldi et al. 2002). The main olive ridley nesting beaches in Brazil are found along a $340 \mathrm{~km}$ continuous span of coastline in the states of Sergipe and northern Bahia, where annual nest numbers have been increasing since 1991 (da Silva et al. 2007). Despite these nesting increases, juvenile and adult olive ridley turtles have been captured by coastal (da Silva et al. 2002, Thomé et al. 2002) and oceanic (Sales et al. 2008) fisheries, constituting a major threat to the turtle population and underscoring the need for effective conservation strategies.

Little is known about post-nesting behavior, female habitat usage and the location of olive ridley foraging grounds in Brazil and regionally, hindering the development of informed management plans. The aim of this study was therefore to investigate the behavior of female olive ridley turtles nesting in northeastern Brazil, with respect to post-nesting movements, migratory routes and foraging grounds. By reporting data on olive ridley movements revealed by satellite telemetry in the Atlantic Ocean basin, this study provides information that is key for the conservation of olive ridley turtles and their habitats in the Western Atlantic, and for better understanding the variable life history patterns of this vulnerable species.

\section{MATERIALS AND METHODS}

The study took place along $21 \mathrm{~km}$ of sandy beaches in northern coastal Sergipe, an important nesting area for olive ridley turtles in Brazil, between 1 February and 4 April 2006 (Fig. $1 ; 10.7^{\circ} \mathrm{S}, 36.7^{\circ}$ to $36.8^{\circ} \mathrm{W}$; for detailed site descriptions see da Silva et al. 2007). Satellite transmitters were attached to 10 female olive ridley turtles (model KiwiSat 101, Sirtrack). Nesting females were located and, following complete oviposition, each turtle was placed in an open wooden box to facilitate transmitter attachment. The second and third medial scutes on the carapace were cleaned, and a satellite tag was attached with Tubolit ${ }^{\circledR}$ epoxy (Mitchell 1998). The attachment was then painted with Micron Premium ${ }^{\circledR}$ anti-fouling paint (International Yatch Paint) and allowed to dry for $45 \mathrm{~min}$, after which turtles were released from the boxes and allowed to crawl into the ocean. Inconel tags (National
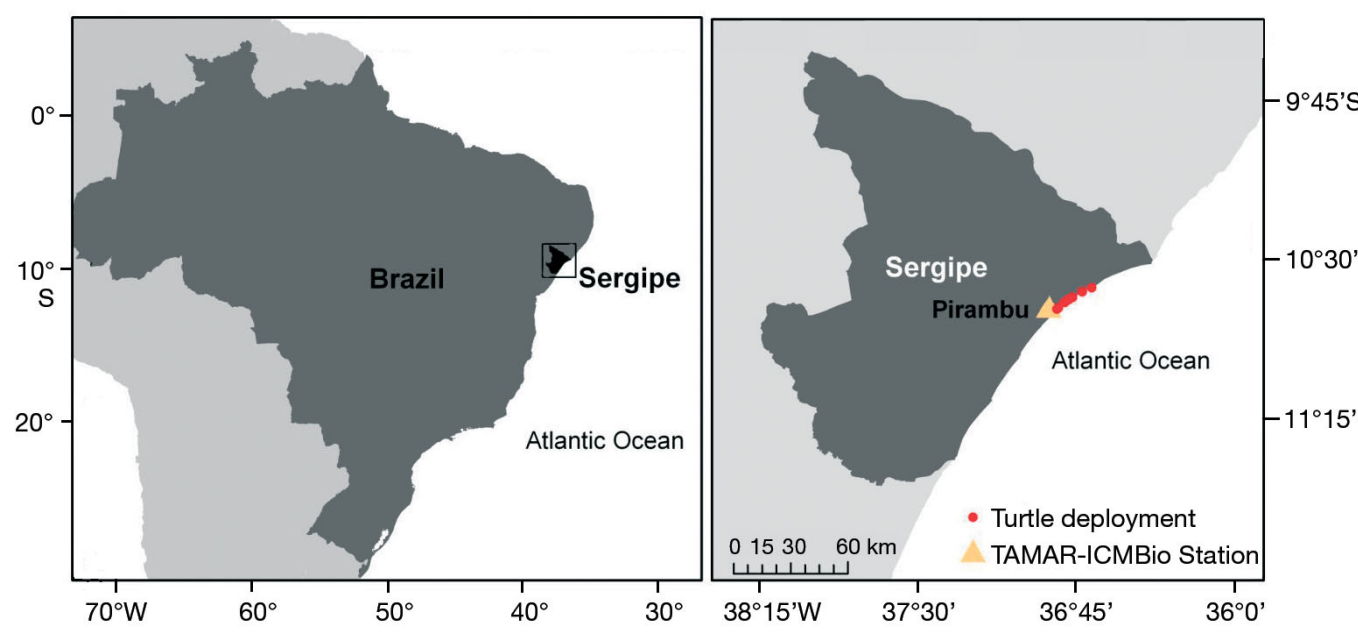

Fig. 1. Study area and locations of transmitter deployment on olive ridley turtles at Pirambu Beach in Sergipe, Brazil. Also shown is the location of the TAMAR-ICMBio conservation research station 
Band and Tag Co.) were also attached to the trailing edge of each front flipper (following Balazs 1999), and curved carapace length (CCL) was measured in $\mathrm{cm}$ (Bolten 1999). Transmitters were powered by $2 \mathrm{D}$-size lithium batteries ( $0.5 \mathrm{~W}$ output), and were configured to work continuously during the first $60 \mathrm{~d}$, and then for $24 \mathrm{~h}$ on $/ 48 \mathrm{~h}$ off.

Data were collected via the Argos system (http:// argosinc.com), which assigned location classes (LC) to each transmission as an estimate of accuracy. The location classes were: LC 3 (accurate to $\pm 150 \mathrm{~m}$ ), LC $2( \pm 350 \mathrm{~m})$, LC $1( \pm 1000 \mathrm{~m})$, LC 0 (accurate to $>1000 \mathrm{~m}$ ), and LCs A, B and Z (of unknown accuracy). The tracking information was automatically downloaded and sorted into fields from the Argos databank using the Satellite Tracking and Analysis Tool (STAT; Coyne \& Godley 2005), which additionally provided information about seafloor depth and distance from the coast to the turtles' locations.

The location classes known to be most accurate (LCs 3, 2, 1 and $A_{i}$ Hays et al. 2001) were used for reconstructing migration routes and estimating distances traveled. We also included LC A, since according to Hays et al. (2001), it has similar accuracy to LC 1. LCs $0, B$ and $Z$, and positions requiring turtles to move at speeds in excess of $5 \mathrm{~km} \mathrm{~h}^{-1}$ were excluded from this analysis. To achieve a better estimate of area usage and avoid excessive data filtration, broaderscale foraging and inter-nesting habitat characterization also relied on LCs B and 0 data, in addition to data from LCs 3, 2, 1 and A. We filtered locations for water depth $>0.5 \mathrm{~m}$, speed $<5 \mathrm{~km} \mathrm{~h}^{-1}$ and angles $<25^{\circ}$.

Inter-nesting habitats were identified based on transmitter signals from turtles that remained in the vicinity of the nesting beach for at least $16 \mathrm{~d}$ after transmitter deployment. Post-nesting migrations were considered complete when movement no longer appeared to be directed for at least 3 consecutive days (Zbinden et al. 2008). Foraging grounds were identified as those areas where turtles showed restricted movements (multidirectional and backtracked over previous tracks) following post-nesting migrations, which continued until transmissions ceased or turtles engaged in new return migrations (Troëng et al. 2005). These areas were defined solely based on turtle movements as it was not possible to verify foraging behavior.

Geographic information systems software (ArcGIS 9.1, Environmental Systems Research Institute) was used to map turtle movements and calculate high-use areas and movement pathways. To define important habitats for each turtle, home ranges based on fixed kernel density estimators were calculated using
Hawth's analysis tools for ArcGIS (Beyer 2004). The minimum convex polygon (MCP) was calculated to determine the total size of foraging and inter-nesting grounds. Core activity areas were defined using 50\% kernel home range estimates (KHREs). Individual and joined core habitat use areas were identified using a single parameter smoothing factor of 0.05 calculated following Silverman (1986). Also calculated were $75 \%$ and $90 \%$ KHREs. The polygonal shapes were measured in $\mathrm{km}^{2}$. Bathymetry was determined by plotting the tracks against nautical charts from the Brazilian Navy (DHN 2009). The tracks were combined with available data on incidental longline fishery captures provided by Sales et al. (2008). Pelagic fishing effort was represented as the total number of hooks in each $5^{\circ} \times 5^{\circ}$ quadrant measured in 2006 . In order to identify potential threats within inter-nesting areas, the turtle's home range and core areas were superimposed with shrimp otter trawl data obtained during TAMAR's monitoring efforts in Sergipe.

\section{RESULTS}

\section{Inter-nesting habitat}

Of the 10 turtles tracked, 6 females (Turtles C, D, F, $\mathrm{H}, \mathrm{I}$ and $\mathrm{J}$ ) remained at the nesting grounds for $35.3 \pm$ $28.2 \mathrm{~d}$ (mean $\pm \mathrm{SD}_{\text {; }}$ range: 20 to $84 \mathrm{~d}$ ) before starting post-nesting migrations, while the remaining 4 females (Turtles A, B, E and G) left the area immediately following nesting and transmitter deployment (Table 1). The MCP analyses revealed that the total area occupied by the turtles that remained at the nesting ground was $5223.8 \mathrm{~km}^{2}$. The core of this area, in which $50 \%$ (KHRE) of the signals were observed, covered $490.9 \mathrm{~km}^{2}$, corresponding to $9.3 \%$ of the total inter-nesting habitat (Fig. 2). The inter-nesting area delineated by the analysis comprised almost all of coastal Sergipe. Most of the signals were transmitted from areas in the vicinity of the capture beach and release location, but signals were also received from both further north and south of this site (Fig. 2). The mean distance from the coast of the turtles tracked during the inter-nesting period was $7 \pm$ $5.6 \mathrm{~km}$ (range: 1 to $36 \mathrm{~km}$ ), and water depths were on average $19.8 \pm 45.7 \mathrm{~m}$ (range: 1 to $420 \mathrm{~m}$ ). The deeper areas were associated with submarine canyons typical of the Sergipe coast. Individual variation in distance and water depth is presented in Table 1.

Of the turtles remaining at the nesting grounds following transmitter attachment, Turtle $\mathrm{H}$ was observed again $20 \mathrm{~d}$ after transmitter attachment during 
Table 1. Lepidochelys olivacea. Transmission data obtained from the 10 olive ridley turtles tracked in this study with respect to their inter-nesting habitat. CCL: curved carapace length. (-): no data (turtles did not nest again)

\begin{tabular}{|c|c|c|c|c|c|c|c|c|}
\hline \multirow[b]{2}{*}{ Turtle } & \multirow[b]{2}{*}{$\begin{array}{l}\text { CCL } \\
(\mathrm{cm})\end{array}$} & \multirow[b]{2}{*}{$\begin{array}{c}\text { Tran } \\
\begin{array}{c}\text { Deployment } \\
\text { date }\end{array} \\
(\mathrm{dd} / \mathrm{mm} / \mathrm{yy})\end{array}$} & \multirow{2}{*}{$\begin{array}{l}\text { mission data } \\
\text { Last } \\
\text { location } \\
\text { (dd/mm/yy) }\end{array}$} & \multirow[b]{2}{*}{$\begin{array}{l}\text { Days } \\
\text { tracked }\end{array}$} & \multirow[b]{2}{*}{$\begin{array}{c}\text { Total } \\
\text { non-linear } \\
\text { distance } \\
\text { tracked }(\mathrm{km})\end{array}$} & \multirow[b]{2}{*}{$\begin{array}{l}\text { Residence } \\
\text { time } \\
\text { (d) }\end{array}$} & - Inter-nesting area & \multirow{2}{*}{$\begin{array}{c}\text { Depth }(\mathrm{m}) \\
\text { mean } \pm \mathrm{SD} \\
(\text { range })\end{array}$} \\
\hline & & & & & & & $\begin{array}{c}\text { Distance from } \\
\text { coast }(\mathrm{km}) \\
\text { mean } \pm \mathrm{SD} \\
\text { (range) }\end{array}$ & \\
\hline $\mathrm{A}$ & 71.0 & $01 / 02 / 06$ & $15 / 02 / 06$ & 14 & 407 & - & - & - \\
\hline $\mathrm{B}$ & 74.5 & 03/02/06 & 05/03/06 & 30 & 430 & - & - & - \\
\hline $\mathrm{C}$ & 70.0 & 04/02/06 & $28 / 11 / 06$ & 297 & 2789 & 84 & $5.6 \pm 5.5(1-23)$ & $17.3 \pm 35.9(1-208)$ \\
\hline $\mathrm{D}$ & 69.0 & $05 / 02 / 06$ & 08/07/06 & 153 & 1137 & 21 & $8.5 \pm 2.6(3-15)$ & $18.5 \pm 8.5(7-46)$ \\
\hline$E$ & 67.5 & 06/02/06 & $16 / 04 / 06$ & 69 & 2402 & - & - & - \\
\hline $\mathrm{F}$ & 71.5 & 08/02/06 & $30 / 04 / 06$ & 81 & 604 & 65 & $5.3 \pm 3.2(1-18)$ & $14.6 \pm 43.8(2-376)$ \\
\hline $\mathrm{G}$ & 68.5 & $11 / 02 / 06$ & 05/07/06 & 144 & 4265 & - & - & - \\
\hline $\mathrm{H}$ & 69.0 & $15 / 02 / 06$ & $11 / 07 / 06$ & 146 & 1645 & 22 & $5.9 \pm 3.9(1-14)$ & $13.2 \pm 8(3-27)$ \\
\hline I & 71.0 & $18 / 02 / 06$ & $30 / 05 / 06$ & 74 & 612 & 31 & $13.9 \pm 6.2(3-30)$ & $50.1 \pm 91.2(1-420)$ \\
\hline $\mathrm{J}$ & 75.5 & 03/04/06 & $12 / 08 / 06$ & 131 & 2400 & 18 & $5 \pm 2.3(2-9)$ & $8 \pm 3.6(1-13)$ \\
\hline
\end{tabular}

a second nesting event on 6 March 2006. According to the telemetry results, Turtles C, F and J probably also nested again in intervals of 20,17 and $18 \mathrm{~d}$, respectively, after the first recorded nesting event and transmitter attachment, but were not recaptured. Monitoring of shrimping vessels within the identified inter-nesting habitat ( $\mathrm{n}=$ 413 hauls) revealed that there is a significant overlap between fishing grounds and core turtle inter-nesting habitats (Fig. 2). The trawl fleet operates in areas up to $30 \mathrm{~m}$ depth, between 3 and $15 \mathrm{~km}$ from shore.

\section{Post-nesting migration}

The turtles left the inter-nesting habitat after all nesting activity was concluded, and moved to neritic areas mainly within the limits of the continental shelf, with only 2 turtles ( $E$ and G) migrating to oceanic areas. Eight turtles (A, B, C, D, F, I, J and H) migrated to neritic areas located in northern, northeastern and southeastern Brazil. Of the 2 turtles that traveled to oceanic areas, one (Turtle E) departed the neritic zone from coastal Alagoas $\left(9.985^{\circ} \mathrm{S}, 35.681^{\circ} \mathrm{W}\right)$, whereas the other (Turtle G) departed from the Paraiba coast $\left(7.459^{\circ} \mathrm{S}, 34.455^{\circ} \mathrm{W}\right.$; Fig. 3, Table 2).

The distance from the nesting beach to neritic foraging grounds averaged $1172.1 \pm 916.7 \mathrm{~km}$ (range:

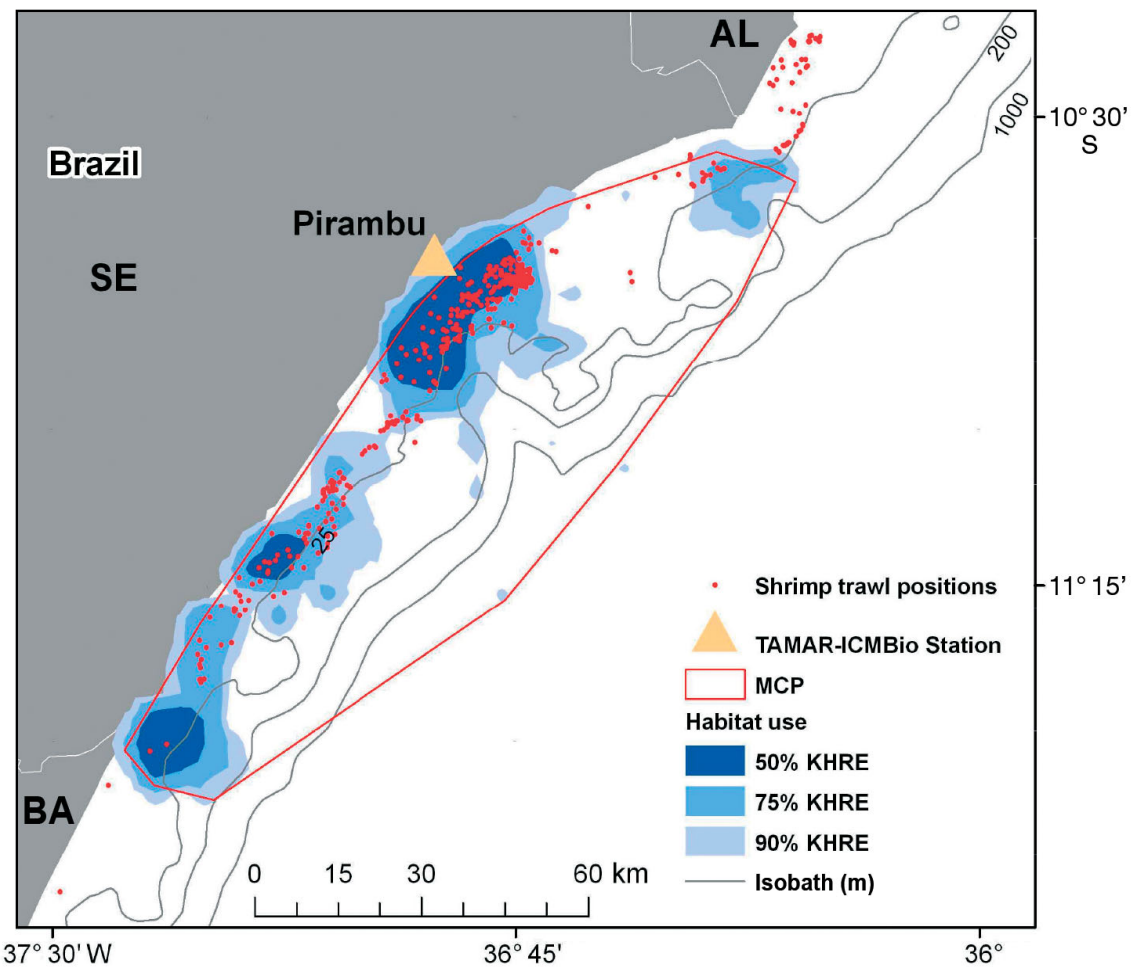

Fig. 2. Lepidochelys olivacea. Inter-nesting positions for olive ridley turtles $(\mathrm{n}=$ 6) nesting at Pirambu Beach (Sergipe, Brazil), with respect to locations of monitored shrimp trawls, isobaths, kernel home range estimates (KHREs; $90 \%$, 75\% and $50 \%$ ) and the minimum convex polygon (MCP). Abbreviations for Brazilian states are as follows: AL, Alagoas; SE, Sergipe; and BA, Bahia

222 to $2300 \mathrm{~km})$. The migration time to foraging areas ranged from 16 to $78 \mathrm{~d}$, with a mean of $40 \pm 25.7 \mathrm{~d}$ (Table 2). Migratory routes were largely restricted to the northeast coast of Brazil, which is characterized by a narrow continental shelf (Fig. 3). The mean seafloor depth during the turtle's migration was $78 \pm 175.6 \mathrm{~m}$. 


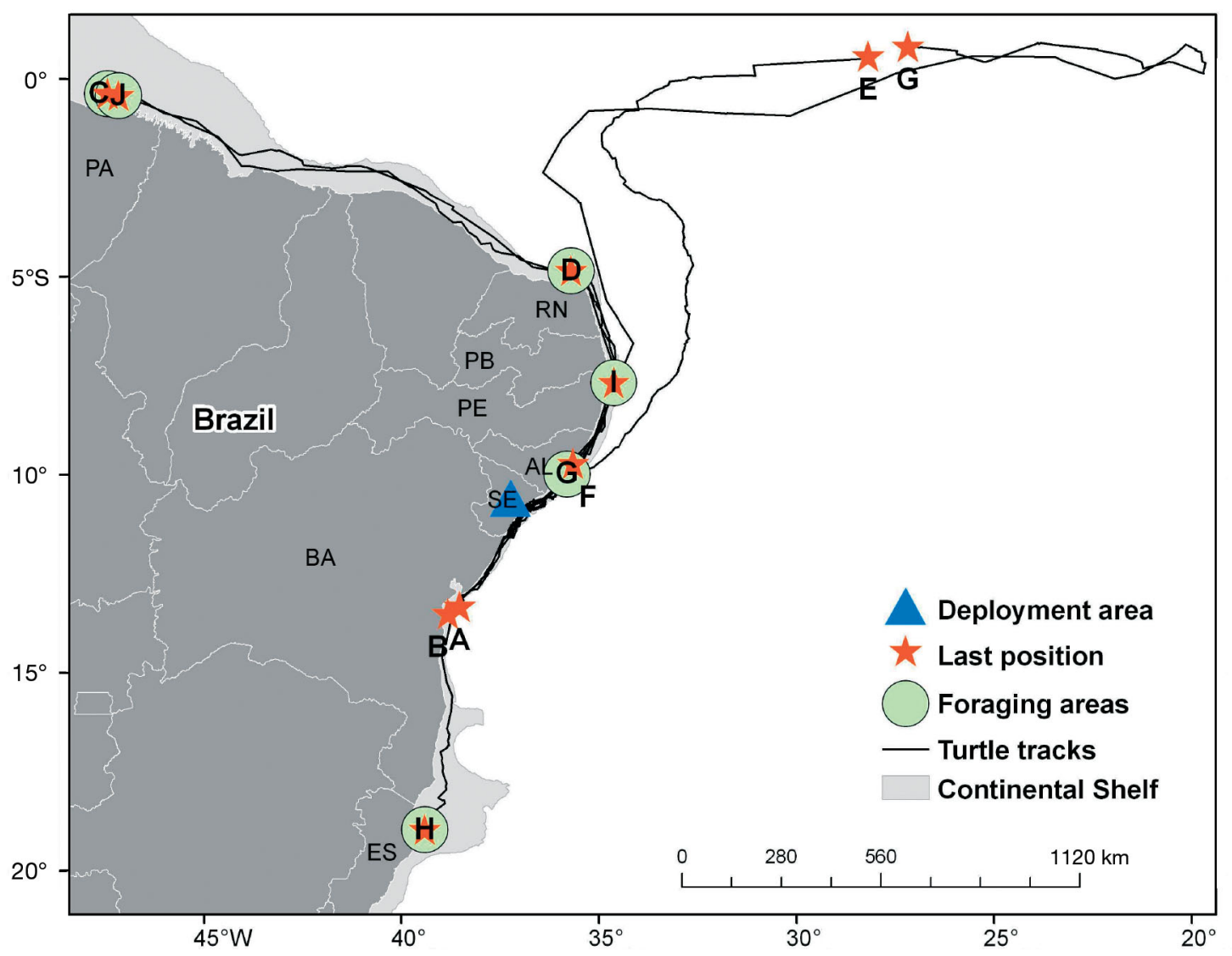

Fig. 3. Lepidochelys olivacea. Post-nesting movements of olive ridley turtles satellitetracked from their nesting grounds in Sergipe $(n=10)$. Stars indicate last position of turtles before signal transmission ceased. Abbreviations for Brazilian states are as follows: PA, Pará; RN, Rio Grande do Norte; PB, Paraíba; PE, Pernambuco; AL, Alagoas; SE, Sergipe; BA, Bahia; ES, Espírito Santo

Table 2. Lepidochelys olivacea. Post-nesting migration and foraging ground residency data collected from satellite-tracked olive ridley turtles $(\mathrm{n}=10)$. Abbreviations for Brazilian states are as follows: PA, Pará; RN, Rio Grande do Norte; PE, Pernambuco; AL, Alagoas; ES, Espírito Santo. (-): missing data or premature signal termination

\begin{tabular}{|c|c|c|c|c|c|c|c|c|c|c|}
\hline \multirow[b]{2}{*}{ Turtle } & \multicolumn{3}{|c|}{ Post-nesting migration } & \multirow[b]{2}{*}{$\begin{array}{c}\text { Foraging } \\
\text { ground } \\
\text { location }\end{array}$} & \multirow[b]{2}{*}{$\begin{array}{c}\text { Arrival } \\
\text { at } \\
\text { foraging } \\
\text { ground } \\
\text { (dd/mm/yy) }\end{array}$} & \multirow[b]{2}{*}{$\begin{array}{l}\text { Distance } \\
\text { from } \\
\text { nesting } \\
\text { grounds } \\
(\mathrm{km})\end{array}$} & \multicolumn{3}{|c|}{ Neritic foraging grounds - } & \multirow[b]{2}{*}{$\begin{array}{c}\text { Depth } \\
(\mathrm{m}) \\
\text { mean } \pm \mathrm{SD} \\
\text { (range) }\end{array}$} \\
\hline & $\begin{array}{c}\text { Departure } \\
\text { from } \\
\text { nesting } \\
\text { area } \\
\text { (dd/mm/yy) }\end{array}$ & $\begin{array}{l}\text { Post- } \\
\text { nesting } \\
\text { migration } \\
\text { (d) }\end{array}$ & $\begin{array}{c}\text { Distance } \\
\text { traveled } \\
(\mathrm{km})\end{array}$ & & & & $\begin{array}{l}\text { Resi- } \\
\text { dency } \\
\text { (d) }\end{array}$ & $\begin{array}{c}50 \% \\
\text { kernel } \\
\text { density } \\
\text { estimates } \\
\left(\mathrm{km}^{2}\right)\end{array}$ & $\begin{array}{c}\text { Distance } \\
(\mathrm{km}) \text { from } \\
\text { coast } \\
\text { mean } \pm \mathrm{SD} \\
\text { (range) }\end{array}$ & \\
\hline $\mathrm{A}$ & 08/02/06 & 14 & 407 & - & - & - & - & - & - & - \\
\hline B & 03/02/06 & 30 & 425 & - & - & - & - & - & - & - \\
\hline $\mathrm{C}$ & 29/04/06 & 78 & 2293 & PA & $16 / 07 / 06$ & 2293 & 135 & 270.61 & $24.4 \pm 3.1(17-31)$ & $18 \pm 2.3(13-21)$ \\
\hline $\mathrm{D}$ & $26 / 02 / 06$ & 26 & 761 & $\mathrm{RN}$ & $24 / 03 / 06$ & 761 & 106 & 164.84 & $31.3 \pm 3.2(22-37)$ & $51.6 \pm 41.4(33-259)$ \\
\hline $\mathrm{E}$ & 06/02/06 & $69^{\mathrm{a}}$ & 2402 & - & - & - & - & - & - & - \\
\hline $\mathrm{F}$ & $18 / 04 / 06$ & 16 & 264 & - & - & - & - & - & - & - \\
\hline $\mathrm{G}$ & $11 / 02 / 06$ & $21^{b}, 89^{c}$ & 4212 & $\mathrm{AL}$ & 04/03/06 & $222^{\mathrm{a}}$ & 34 & 35.18 & $10.6 \pm 2.3(4-13)$ & $15.3 \pm 2.3(9-18)$ \\
\hline $\mathrm{H}$ & 09/03/06 & 33 & 1051 & ES & $11 / 04 / 06$ & 1051 & 91 & 273.61 & $41.0 \pm 10.1(29-72)$ & $31.9 \pm 6.1(21-44)$ \\
\hline I & $21 / 03 / 06$ & 16 & 406 & $\mathrm{PE}$ & 06/04/06 & 406 & 27 & 114.64 & $21.9 \pm 4.0(17-31)$ & $42.2 \pm 9.2(33-72)$ \\
\hline $\mathrm{J}$ & $21 / 04 / 06$ & 66 & 2300 & PA & $26 / 06 / 06$ & 2300 & 47 & 184.15 & $23.4 \pm 3.7(18-29)$ & $19.6 \pm 1.2(16-21)$ \\
\hline
\end{tabular}


Transmissions from 3 post-nesting turtles (A, B, and F) ceased before they reached neritic foraging grounds or oceanic waters. The total displacement of these turtles was 407,430 and $264 \mathrm{~km}$ over 14, 30 and $81 \mathrm{~d}$, respectively (Fig. 3, Tables 1 \& 2).

The satellite transmissions from Turtle $\mathrm{H}$, which moved to a foraging area south of the nesting beach, were almost always within the limits of the continental shelf, which on the north coast of Bahia is the narrowest in all of Brazil. The movements occurred between the 25 to $50 \mathrm{~m}$ isobaths, and at some places Turtle $\mathrm{H}$ moved off the continental shelf. Upon reaching the Abrolhos Bank, where the continental shelf is wider, the turtle moved further away from the coast, but remained in waters 25 to $50 \mathrm{~m}$ deep. As such, in both northern and southern Brazil these movements took place within the confines of the continental shelf, even though the turtle was more distant from the coast where the continental shelf was wider (Fig. 3 , Table 2).

Two turtles ( $\mathrm{E}$ and $\mathrm{G}$ ) moved to oceanic waters after being tracked along the continental shelf. Turtle E moved north off the coast towards the equator, then east until transmissions ceased (at $0.606^{\circ} \mathrm{S}, 28.162^{\circ} \mathrm{W}$ ), covering $2400 \mathrm{~km}$ in $69 \mathrm{~d}$ (Fig. 3, Tables 1 \& 2). Turtle $\mathrm{G}$ displayed unique behavior, by first moving from the nesting grounds across the continental shelf to a neritic foraging ground in Alagoas, where she remained for $34 \mathrm{~d}$. Then, she moved north again along the continental shelf to Paraiba, and then off the Brazilian coast to oceanic waters. Her signals were traced eastwards along equatorial regions to the MidAtlantic Ridge, and then back westwards until transmissions ceased (at $0.805^{\circ} \mathrm{S}, 27.204^{\circ} \mathrm{W}$ ), moving a total of $4265 \mathrm{~km}$ in $144 \mathrm{~d}$ (Fig. 3, Tables 1 \& 2). The locations from which the last signals from Turtles $E$ and $G$ were received were $111 \mathrm{~km}$ apart.

The oceanic movements of Turtles E and $\mathrm{G}$ were carried out over an area intensively utilized by the longline fleet, including mostly international vessels whose cruises last approximately $2 \mathrm{mo}$, and which operate at levels considerably higher (between 2000 and 2500 hooks per set) than those of the national fleet (between 1000 and
1300 hooks per set). Among the 5 sea turtle species found in the South Atlantic Ocean (loggerhead Caretta caretta, leatherback Dermochelys coriacea, green turtle Chelonia mydas, olive ridley, and hawksbill Eretmochelys imbricata), to our knowledge only the hawksbill has never been reported as incidentally caught by longlines in this region (Sales et al. 2008).

The northeast and northern Brazilian coast and the adjacent international waters are also known for having the highest rates of olive ridley captures by longlines in Brazil and adjacent international waters (Sales et al. 2008), suggesting that marine sites around northern Brazil are preferential habitat for this species. In 2006, the year in which the monitoring efforts reported here were conducted, at least 130 olive ridley turtle captures by the Brazil-based longline fleet were recorded. Of these, 83 turtles were captured within the quadrants traversed by the females tracked in this study (Fig. 4).

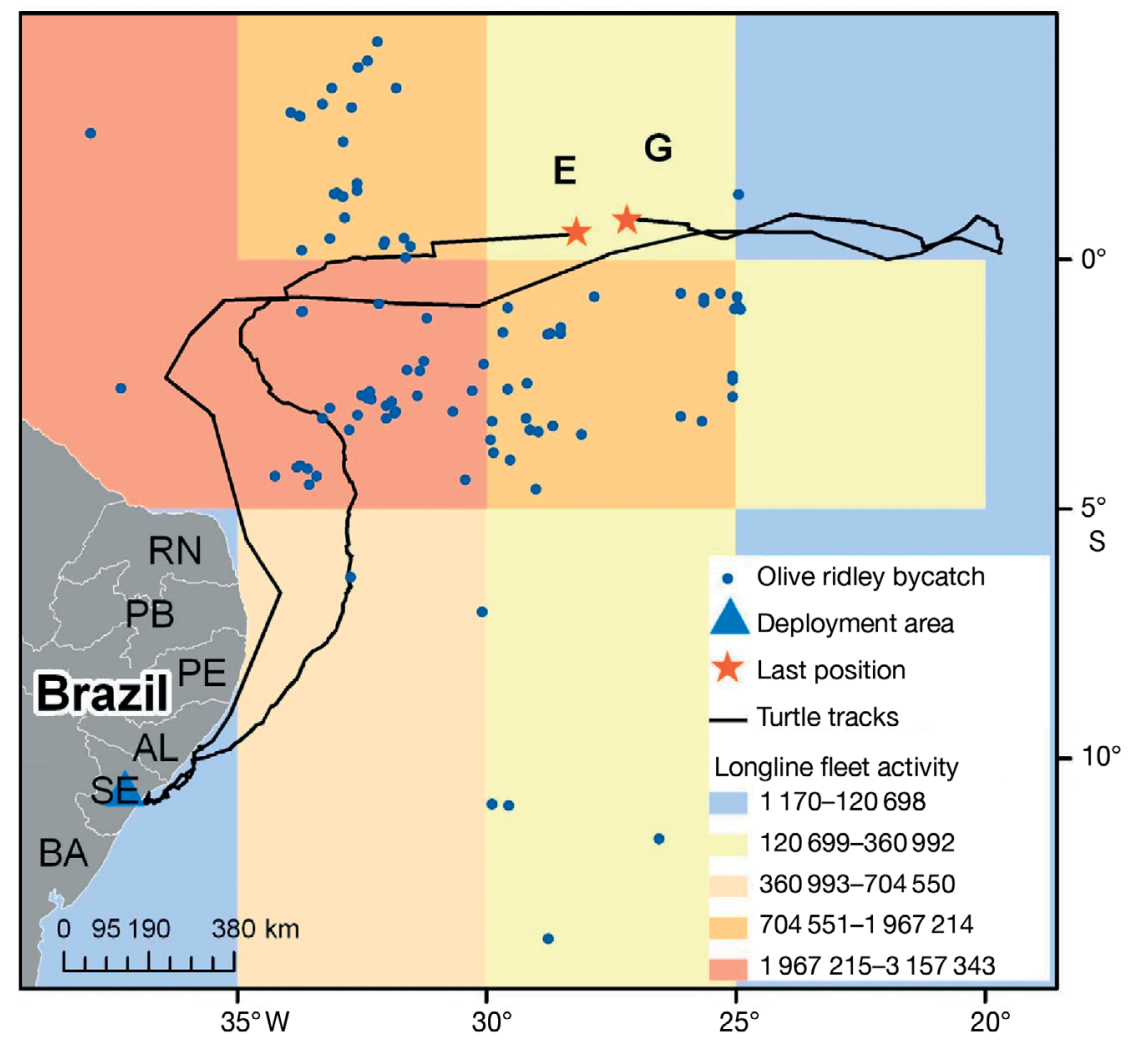

Fig. 4. Lepidochelys olivacea. Satellite tracks for Turtles E and G, and overlap with pelagic fishing activity and turtle bycatch sites $(n=130)$ recorded in 2006. Longline fleet activity is shown as the total number of hooks per $5^{\circ} \times 5^{\circ}$ quadrant. Abbreviations for Brazilian states are as follows: RN, Rio Grande do Norte;

PB, Paraíba; PE, Pernambuco; AL, Alagoas; SE, Sergipe; and BA, Bahia 


\section{Foraging grounds}

Six female olive ridley turtles (Turtles C, D, G, H, I and $\mathrm{J}$ ) reached neritic foraging grounds along the Brazilian coast. The foraging grounds were located mainly to the north of the nesting areas, along the coasts of Pará, Rio Grande do Norte and Alagoas, and between Pernambuco and Paraíba, whereas only 1 turtle moved south to Espírito Santo (Fig. 5, Table 2).
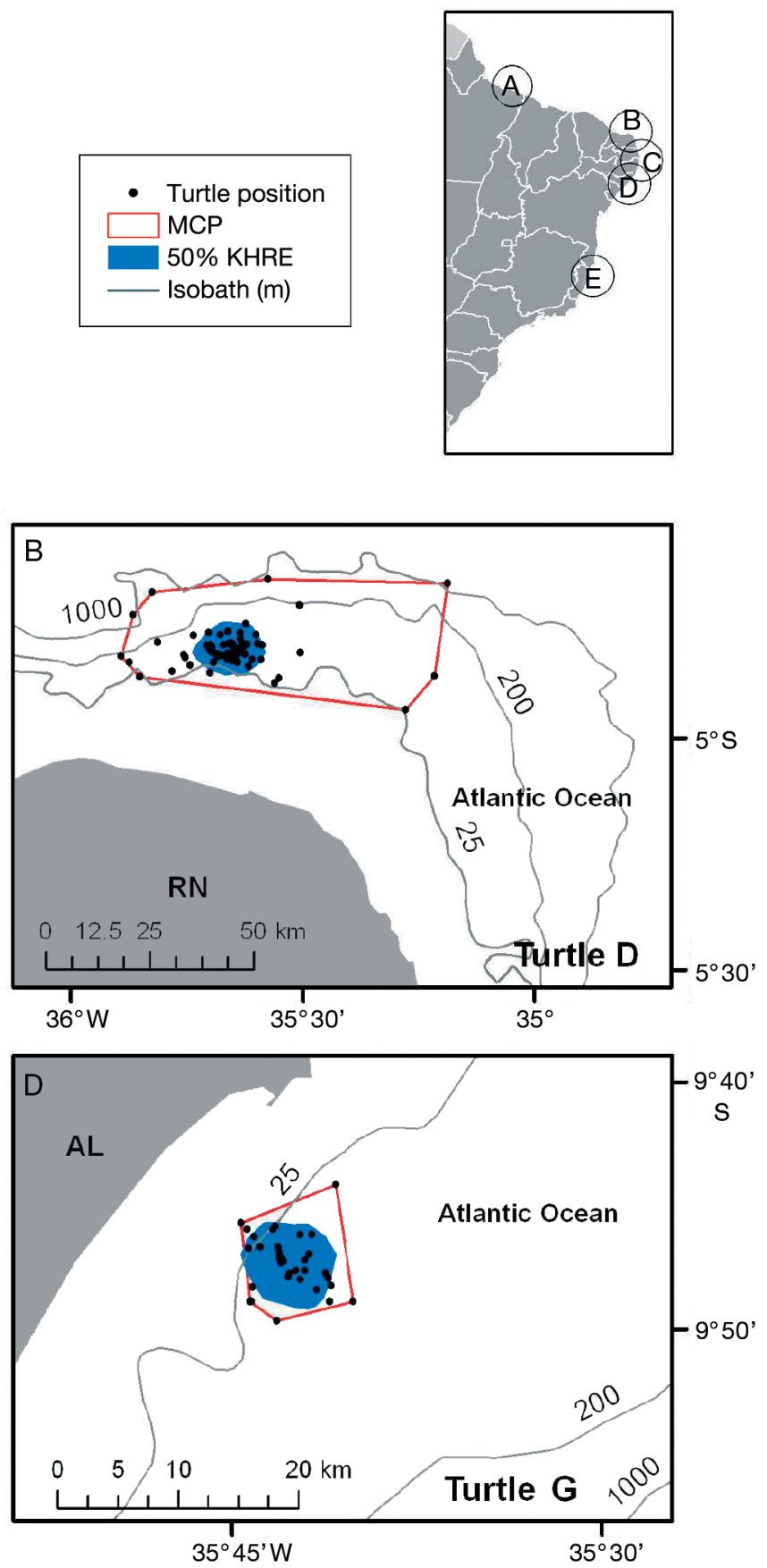
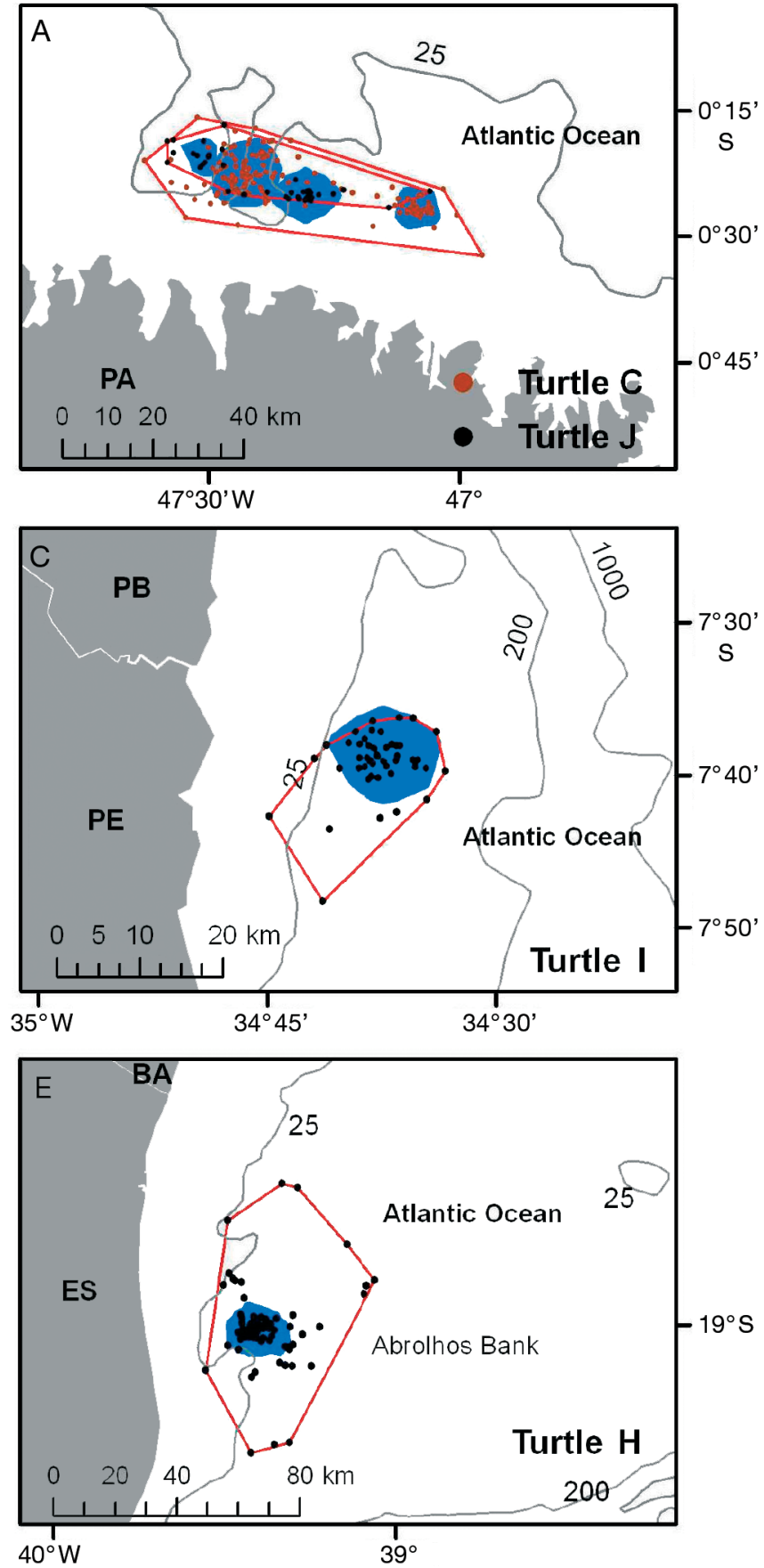

Fig. 5. Lepidochelys olivacea. Olive ridley foraging areas along the north/northeastern and southeastern coasts of Brazil. Closeup views of foraging destinations of olive ridleys: (A) Turtles C and $\mathrm{J}_{i}(\mathrm{~B})$ Turtle $\mathrm{D}_{i}$ (C) Turtle $\mathrm{I}_{i}$ (D) Turtle G; and (E) Turtle H. Overall foraging areas for each turtle were delineated by minimum convex polygons (MCPs), and core use areas were identified using 50 \% kernel home range estimates (KHREs). Abbreviations for Brazilian states are as follows: PA, Pará; RN, Rio Grande do Norte; PB, Paraíba; PE, Pernambuco; AL, Alagoas; BA, Bahia; ES, Espírito Santo. Figures are shown at varying scales for clarity 
The turtles transmitted for a mean period of $73 \pm$ $42.7 \mathrm{~d}$ (range: 34 to $135 \mathrm{~d}$ ). The shortest period was for Turtle G, and the longest for Turtle C, which shared the area with the foraging Turtle J (Table 2). The mean size of the foraging areas (MCP) was $1141 \pm 1066 \mathrm{~km}^{2}$ (range: 60.7 to $2806 \mathrm{~km}^{2}$ ). The core areas (50\% KHRE) averaged $173.8 \pm 91.9 \mathrm{~km}^{2}$ (range: 35 to $270 \mathrm{~km}^{2}$ ). The largest foraging areas were located on the northern (Pará, Turtles C and J) and southeastern (Espírito Santo, Turtle H) coasts of Brazil, whereas the smallest area, which was identified based on transmissions from Turtle G, was in northeastern Brazil. The foraging areas were located at a mean distance from shore of 10 to $41 \mathrm{~km}$, with mean depths of 15 to $51 \mathrm{~m}$.

\section{DISCUSSION}

In the past few decades, research on sea turtle behavior in marine habitats has increased considerably largely because of improvements in satellite telemetry; however, satellite tagging of olive ridleys has lagged behind other marine turtle species (Godley et al. 2008). Analysis of the post-nesting movements of female olive ridleys of Brazil led to the following conclusions: (1) the inter-nesting habitat comprised extensive areas in waters along almost all of Sergipe, and the turtles apparently remained active during this period; (2) the migration routes included continental shelf areas as well as oceanic equatorial waters; and (3) the feeding grounds were located predominantly on the continental shelf; however, one-fifth of the turtles monitored also carried out post-nesting movements to oceanic waters.

\section{Inter-nesting habitat}

The data collected from nesting females in Sergipe indicates that they occupy a relatively large area (approximately $5000 \mathrm{~km}^{2}$ ) along the continental shelf and slope of Brazil during the inter-nesting period, which significantly overlaps with fishing activity. Location data received before the start of post-nesting migrations tended to be clumped in areas to the north and south of the nesting beach where turtles were originally outfitted with satellite tags, and some turtles moved between these 2 areas before migrating away from the nesting beach.

The results suggest that female olive ridley turtles from this population were actively moving during the inter-nesting period. The inter-nesting habitat identified in this study houses abundant shrimp populations (Litopenaeus schmitti, Farfantepenaeus subtilis and Xiphopenaeus kroyeri), and is fished by medium-sized $(<12 \mathrm{~m})$ shrimp trawlers (IBAMA 2004). Stranded olive ridley turtles (including reproductive females) are frequently recorded in this region (da Silva et al. 2002, de Castilhos \& Tiwari 2006). Shrimp and other marine invertebrates are commonly found in the gastrointestinal tracts of dead adult olive ridley turtles stranding during the nesting season (da Silva et al. 2002, de Castilhos \& Tiwari 2006, Colman 2009). Perhaps reproductive females in Sergipe are taking advantage of the presence of suitable prey in the vicinity of the nesting beach and actively foraging during the inter-nesting period.

The shrimp trawl fishery must close between 1 April and 15 May and between 1 December and 15 January of each year, according to the Brazilian Ministry of the Environment (Normative Instruction no. 14, 14 October 2004). The latter closure period overlaps with the peak regional nesting season for olive ridleys (da Silva et al. 2007). The same law also states that, to protect reproductive female turtles during the nesting season, shrimp trawling is prohibited in waters less than 2 nautical miles from the shore.

The tracking results presented here, however, showed that inter-nesting habitat occurred well beyond this $2 \mathrm{n}$ mile limit, and that there was significant overlap between inter-nesting habitat and fishing areas, leading to a search for management options. The $2 \mathrm{n}$ miles where fishing is prohibited cover only $7.3 \%$ of the total inter-nesting habitat delineated in this study, and $28.7 \%$ of the core area. Further, a large overlap between fishing areas and internesting habitat was evident from the results of this study and recent monitoring activities carried out by the Brazilian Sea Turtle Conservation Programme (Projeto TAMAR ICMBio). The surveys and documentation provided by fishers indicated that shrimp trawling along Sergipe's coast occurs mainly between the 5 and $30 \mathrm{~m}$ isobaths, where inter-nesting habitat was also located (50\% and $75 \%$ KHRE). Several participatory discussion forums and co-management events were instituted to identify a solution to the problem of incidental capture of turtles in these fisheries (da Silva et al. 2010). Extending the summer closure period beyond the current $45 \mathrm{~d}$ (1 December to 15 January) to enhance protection during the peak olive ridley breeding season stood out amongst the proposals discussed. 


\section{Post-nesting movements}

Post-nesting movements were directed to neritic foraging areas ( $\mathrm{n}=6$ turtles), whereas only 1 turtle moved immediately to the pelagic without utilizing these feeding grounds. Despite the variation commonly reported in telemetry studies (see Godley et al. 2008), the general post-nesting behavior pattern observed here was of migration along the continental shelf to neritic foraging grounds (A1 type movements, following Godley et al. 2008), and multiple habitat use. Even the 2 turtles with tracks to oceanic areas included 1 turtle that first spent nearly a month in a neritic feeding ground; both turtles moved along the shelf during earlier stages of migration (A1/B type movements according to Godley et al. 2008).

Studies of Australian populations (McMahon et al. 2007, Whiting et al. 2007) indicate multiple coastal habitat use, including shallow coastal habitats, continental shelf and continental slope, and foraging upon either oceanic or neritic prey. In the present study, the use of multiple habitats was also observed, but while in Australia the female olive ridley turtles remained over the continental shelf and slope, in our study 2 females also moved to oceanic waters. A complex foraging strategy was apparent in the case of Turtle G, which, after nesting, migrated $222 \mathrm{~km}$ north and remained at a foraging ground on the continental shelf for $34 \mathrm{~d}$ (with mean water depths of $15.3 \pm 2.3 \mathrm{~m}$ ) before moving away from the Brazilian coast towards the Mid-Atlantic Ridge.

Studies on post-reproductive behavior of olive ridley turtles around the world have shown different foraging strategies in different regions, such as the prevalence of oceanic movements in the eastern tropical Pacific (Plotkin 2010) or shuttling to continental shelf and slope waters in Australia (Whiting et al. 2007), which are possibly related to the oceanographic characteristics of each particular region (Bolten 2003). Post-nesting olive ridleys from Brazil displayed both coastal and oceanic movements; although most of the turtles remained within neritic waters, one individual performed both types of movements, evidencing the behavioral plasticity of post-reproductive olive ridley females.

The results of the present study further suggest that post-nesting olive ridleys from Sergipe might be threatened by several different fishing operations known to have high potential for interacting with sea turtles (Thomé et al. 2002). Marcovaldi et al. (2006) identified 16 different coastal fisheries that interacted with sea turtles along the Brazilian coast, including along the observed continental shelf migra- tory routes. Longline fishing is employed by Brazilian and foreign ships working out of ports located along the Brazilian northeastern coast. In addition to the potential fisheries threats along the migratory routes and at neritic foraging grounds, onboard observer coverage of oceanic longline vessels revealed that the region between $10^{\circ} \mathrm{N}$ and $10^{\circ} \mathrm{S}$ was characterized by high fishing effort (Sales et al. 2008) underscoring the potential for interaction between turtles and fishing effort in this part of the Atlantic. One of the tracked turtles (E) stopped transmitting as soon as she reached this fishery area; a second one (G) stayed there for $42 \mathrm{~d}$ until transmissions ceased. It is not possible to assert that these turtles were caught by the fishery, but this area is an important longline location where many olive ridley turtles are known to be incidentally caught (Sales et al. 2008).

\section{Conservation implications}

Recently, the numbers of nests laid annually in Brazil have increased, suggesting that beach-level protection of nesting females and their eggs has contributed to a positive population trend (da Silva et al. 2007). However, turtles constantly strand along the nesting beaches, and $75 \%$ of these turtles are larger than the smallest recorded nesting female $(64 \mathrm{~cm}$ CCL), indicating extensive overlap of nesting and stranded turtles in terms of size. Evidence of egg formation in several necropsied olive ridley turtles confirmed they were nesting females (da Silva et al. 2010). These findings are of concern because, despite the remarkable increase in the number of clutches, the take (by fishery bycatch or other causes) of reproductive-age turtles of high 'reproductive value' may eventually hinder the recovery of the groups nesting in this area.

Incidental fishery captures of juveniles and adults in neritic (da Silva et al. 2002, Thomé et al. 2002, Becker et al. 2007, Lima \& Melo 2007, Sales et al. 2007) as well as oceanic waters (Sales et al. 2008) remain a major threat to olive ridleys nesting in Sergipe. Although it is not possible to assert here that any single monitored female was captured by coastal or oceanic fisheries, the results highlight the overlap of habitats used by female olive ridleys during their inter-nesting movements, migrations and foraging activities in Brazil with several coastal and oceanic fisheries.

This overlap represents a difficulty for conservation actions because the mitigation and monitoring efforts require a broad and challenging focus - on 
incidental capture both in coastal and small-scale fisheries, as well as the industrial oceanic fishing industry. With respect to the coastal fisheries, the vast scale of the Brazilian coast and the diversity of fisheries, such as shrimp trawls and gillnets targeting fishes and lobsters (Thomé et al. 2002), present a significant challenge. Management efforts in this direction are focusing on fishery monitoring programs (Marcovaldi et al. 2002) and co-management processes (da Silva et al. 2010), which can be improved based on the results of the present study among other research. In the case of the longline oceanic fishery, there is a substantial fishing effort by Brazilian and foreign vessels using international waters off the Brazilian coast, including areas where the females were tracked, which requires international conservation efforts. Conservation advances are being achieved by monitoring this fishery using onboard observers (Sales et al. 2008).

In conclusion, it was evident from this study in comparison to others that olive ridleys have multiple post-nesting foraging strategies around the world and utilize different habitats in coastal and oceanic waters, perhaps because of resource availability in each region (Plotkin et al. 1995, Bolten 2003, Whiting et al. 2007). Further studies using satellite telemetry associated with other techniques and environmental data could help to better understand the habitats used by female olive ridley turtles and inform the establishment of conservation strategies for the West Atlantic and globally.

Acknowledgements. We are grateful to Centro de Pesquisas da PETROBRAS (CENPES/PETROBRAS) for supporting the 'Mamíferos e Quelônios Marinhos' project, which included this study. We are also grateful to Conselho Nacional de Desenvolvimento Científico e Tecnológico (CNPq, PhD scholarship to T.Z.S., process number 141361/2010-7). We thank all TAMAR staff that participated in the deployment of the satellite transmitters. We also thank M. Godfrey, E. Naro-Maciel, M. Lopez Mendilaharsu and 5 anonymous reviewers for providing constructive comments that improved the quality of the manuscript. Projeto TAMAR, a conservation program of the Brazilian Ministry of the Environment, is affiliated with ICMBio and is co-managed by Fundação Pró-TAMAR and officially sponsored by Petrobras.

\section{LITERATURE CITED}

Abreu-Grobois FA, Plotkin P (2008) Lepidochelys olivacea. In: IUCN 2010. IUCN Red List of Threatened Species. Version 2010.4. Available at www.iucnredlist.org

Balazs GH (1999) Factors to consider in the tagging of sea turtles. In: Eckert KE, Bjorndal KA, Abreu-Grobois FA, Donnelly M (eds) Research and management techniques for the conservation of sea turtles. IUCN/SSC Marine
Turtle Specialist Group Publication 4, Washington, DC, p 1-10

Becker JH, Gallo B, Macedo S, Almeida BADL and others (2007) Captura incidental de tartarugas marinhas em cercos flutuantes em Ubatuba, São Paulo, Brazil. In: Libro de resumenes 3rd Jornada de Conservación e investigación de tortugas marinas em el Atlántico Sur Occidental, Piriápolis, p 44-45

Beyer HL (2004) Hawth's analysis tools for ArcGIS. Available at www.spatialecology.com/htools

Bolten AB (1999) Techniques for measuring sea turtles. In: Eckert KE, Bjorndal KA, Abreu-Grobois FA, Donnelly M (eds) Research and management techniques for the conservation of sea turtles. IUCN/SSC Marine Turtle Specialist Group Publication 4, Washington, DC, p 110-114

Bolten AB (2003) Variation in sea turtle life history patterns: neritic vs. oceanic developmental stages. In: Lutz PL, Musick JA, Wyneken J (eds) The biology of sea turtles, Vol 2. CRC Press, Boca Raton, FL, p 243-257

Bowen BW, Clark AM, Abreu-Grobois FA, Chaves A, Reichart HA, Ferl RJ (1998) Global phylogeography of the ridley sea turtles (Lepidochelys spp.) as inferred from mitochondrial DNA sequences. Genetica 101:179-189

Colman LP (2009) Dieta da tartaruga-oliva Lepidochelys olivacea (Eschscholtz, 1829) no litoral do estado de Sergipe, Brasil. Graduate monograph. Universidade Federal da Bahia. Bahia

> Coyne MS, Godley BJ (2005) Satellite Tracking and Analysis Tool (STAT): an integrated system for archiving, analyzing and mapping animal tracking data. Mar Ecol Prog Ser 301:1-7

da Silva ACCD, de Castilhos JC, Rocha DAS, Oliveira FLC, Weber M (2002) Mortalidade de tartarugas marinhas no entorno de sítios de reprodução no Estado de Sergipe, Brasil. In: Mazzoleni RC, Souto FX, Lacava LA, Braun JRR (eds) Resumos 24th Congresso Brasileiro de Zoologia, Itajaí. Editora e Gráfica Berger, Itajaí, p 453-454

> da Silva ACCD, de Castilhos JC, Lopez G, Barata PCR (2007) Nesting biology and conservation of the olive ridley sea turtle (Lepidochelys olivacea) in Brazil, 1991/1992 to 2002/2003. J Mar Biol Assoc UK 87:1047-1056

da Silva ACCD, de Castilhos JC, dos Santos EAP, Brondízio LS, Bugoni L (2010) Efforts to reduce sea turtle bycatch in the shrimp fishery in northeastern Brazil through a comanagement process. Ocean Coast Manag 53:570-576

de Castilhos JC, Tiwari M (2006) Preliminary data and observations from an increasing olive ridley population in Sergipe, Brazil. Mar Turtle Newsl 113:6-7

DHN (Diretoria de Hidrografia e Navegação) (2009) Coletânea de cartas náuticas. Diretoria de Hidrografia e Navegação, Comando da Marinha. Available at https: //www.mar.mil.br/dhn/chm/cartas/download/cartasbsb/ cartas_eletronicas_Internet.htm

Eguchi T, Gerrodette T, Pitman RL, Seminoff JA, Dutton PH (2007) At-sea density and abundance estimates of the olive ridley turtle Lepidochelys olivacea in the eastern tropical Pacific. Endang Species Res 3:191-203

Fretey J (1999) Repartition des tortues du genre Lepidochelys Fitzinger, 1843. I. L'Atlantique Ouest. Biogeographica 75:97-117

Fretey J (2001) Biogeography and conservation of marine turtles of the Atlantic coast of Africa. CMS Technical Series Publication no. 6, UNEP/CMS Secretariat, Bonn

Godfrey MH, Chevalier J (2004) The status of olive ridley sea turtles in the West Atlantic. Report requested by the 
olive ridley assessment group of the Marine Turtle Specialist Group - SSC/IUCN. Available at http://members. seaturtle.org/godfreym/Godfrey2004MTSG.pdf

Godley BJ, Blumenthal JM, Broderick AC, Coyne MS, Godfrey MH, Hawkes LA, Witt MJ (2008) Satellite tracking of sea turtles: Where have we been and where do we go next? Endang Species Res 4:3-22

Hays GC, Åkesson S, Godley BJ, Luschi P, Santidrian P (2001) The implications of location accuracy for the interpretation of satellite tracking data. Anim Behav 61: 1035-1040

IBAMA (Instituto Brasileiro do Meio Ambiente e dos Recursos Naturais Renováveis) (2004) Boletim Estatístico da Pesca Marítima e Estuarina do Nordeste do Brasil — 2003. Ministério do Meio Ambiente, IBAMA, CEPENE, Brasília

Lima EHSM, Melo MTD (2007) Registros de tartarugas marinhas capturadas acidentalmente em manzuá para peixe observado pelo Projeto TAMAR-ICMBio, Ceará em 2006. In: Estrades A (ed) Libro de resumenes 3rd Jornada de Conservación e investigación de tortugas marinas em el Atlántico Sur Occidental, Piriápolis, p 59-60

Marcovaldi MÂ, dei Marcovaldi GG (1999) Marine turtles of Brazil: the history and structure of Projeto TAMARIBAMA. Biol Conserv 91:35-41

Marcovaldi MA, Thomé JC, Sales G, Coelho AC, Gallo B, Bellini C (2002) Brazilian plan for reduction of incidental sea turtle capture in fisheries. Mar Turtle Newsl 96: 24-25

Marcovaldi MÂ, Sales G, Thomé JCA, da Silva ACCD and others (2006) Sea turtle and fishery interactions in Brazil: identifying and mitigating potential conflicts. Mar Turtle Newsl 112:4-8

McMahon CR, Bradshaw CJA, Hays GC (2007) Satellite tracking reveals unusual diving characteristics for a marine reptile, the olive ridley turtle Lepidochelys olivacea. Mar Ecol Prog Ser 329:239-252

Mitchell SV (1998) Use of epoxy in telemeter attachment. In: Abreu-Grobois FA, Briseño-Duenas R, Márquez-Millán R, Sarti-Martínez L (eds) Proc 18th Int Symp Sea Turtle Biol Conserv. NOAA Tech Memo NMFS-SEFSC 436: 254-255

Plotkin PT (2010) Nomadic behaviour of the highly migratory olive ridley sea turtle Lepidochelys olivacea in the eastern tropical Pacific Ocean. Endang Species Res 13: 33-40

Plotkin PT, Byles RA, Rostal DC, Owens DW (1995) Inde-

Editorial responsibility: Hans Heinrich Janssen, Oldendorf/Luhe, Germany pendent versus socially facilitated oceanic migrations of the olive ridley, Lepidochelys olivacea. Mar Biol 122: 137-143

Polovina JJ, Balazs GH, Howell EA, Parker PG, Seki MP, Dutton PH (2004) Forage and migration habitat of loggerhead (Caretta caretta) and olive ridley (Lepidochelys olivacea) sea turtles in the central North Pacific Ocean. Fish Oceanogr 13:36-51

Pritchard PCH (1997) Evolution, phylogeny, and current status. In: Lutz PL, Musick JA (eds) The biology of sea turtles. CRC Press, Boca Raton, FL, p 2-23

Sales G, Lopez GG, Santos AS, Vianna P, Serafini TZ (2007) Captura incidental de tartarugas marinhas na pesca artesanal registrada pelo projeto TAMAR-IBAMA no litoral norte da Bahia, Brasil. In: Anais 12th Congresso Latino Americano de Ciências do Mar, Florianópolis. AOCEANO-Associação Brasileira de Oceanografia, Florianópolis, p 282

Sales G, Giffoni BB, Barata PCR (2008) Incidental catch of sea turtles by the Brazilian pelagic longline fishery. J Mar Biol Assoc UK 88:853-864

Silverman BW (1986) Density estimation for statistics and data analysis. Chapman \& Hall, London

Swimmer Y, McNaughton L, Foley D, Moxey L, Nielsen A (2009) Movements of olive ridley sea turtles Lepidochelys olivacea and associated oceanographic features as determined by improved light-based geolocation. Endang Species Res 10:245-254

Thomé JCA, Marcovaldi MÂ, dei Marcovaldi GG, Bellini C and others (2002) An overview of Projeto TAMARIBAMA's activities in relation to the incidental capture of sea turtles in Brazilian fisheries. In: Salmon M, Wyneken J (eds) Proc 11th Annu Symp Sea Turtle Biol Conserv. NOAA Tech Mem NMFS-SEFSC 302, Miami, FL, p 119-120

Troëng S, Evans DR, Harrison E, Lagueux CJ (2005) Migration of green turtles Chelonia mydas from Tortuguero, Costa Rica. Mar Biol 148:435-447

Whiting SD, Long JL, Coyne M (2007) Migration routes and foraging behaviour of olive ridley turtles Lepidochelys olivacea in northern Australia. Endang Species Res 3:1-9

Zbinden JA, Aebischer A, Margaritoulis D, Arlettaz R (2008) Important areas at sea for adult loggerhead sea turtles in the Mediterranean Sea: satellite tracking corroborates findings from potentially biased sources. Mar Biol 153: 899-906

Submitted: March 1, 2010; Accepted: September 26, 2011 Proofs received from author(s): December 2, 2011 